\title{
Ana Cristina Mendes, Salman Rushdie in the Cultural Marketplace
}

Sabine Lauret

\section{(2) OpenEdition \\ 12 Journals}

Electronic version

URL: https://journals.openedition.org/ces/5735

DOI: $10.4000 /$ ces.5735

ISSN: 2534-6695

Publisher

SEPC (Société d'études des pays du Commonwealth)

\section{Printed version}

Date of publication: 1 September 2014

Number of pages: 113-114

ISSN: 2270-0633

\section{Electronic reference}

Sabine Lauret, "Ana Cristina Mendes, Salman Rushdie in the Cultural Marketplace", Commonwealth Essays and Studies [Online], 37.1 | 2014, Online since 14 April 2021, connection on 18 July 2021. URL: http://journals.openedition.org/ces/5735 ; DOI: https://doi.org/10.4000/ces.5735

This text was automatically generated on 18 July 2021 .

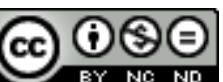

Commonwealth Essays and Studies is licensed under a Licence Creative Commons Attribution - Pas d'Utilisation Commerciale - Pas de Modification 4.0 International. 


\title{
Ana Cristina Mendes, Salman Rushdie in the Cultural Marketplace
}

\author{
Sabine Lauret
}

\section{REFERENCES}

Ana Cristina Mendes. Salman Rushdie in the Cultural Marketplace. Surrey: Ashgate, 2013. 199 p. ISBN (hb): 9781409446736 . ISBN (PDF ebook): 9781409446743. ISBN (epub): 9781472406224. £60

1 Ana Cristina Mendes' Salman Rushdie in the Cultural Marketplace proposes an original reading of Rushdie's work as it sets out to examine an aspect that critics have not fully developed yet: Rushdie is examined as a landmark, and as a literary product.

Mendes' analysis homes in on Rushdie's magpie tendency, and shows that in collecting cultural items, he has become more than just a landmark in the cultural marketplace. To some extent, the study mimics the very process it captures. After a dense introduction that exposes the theoretical apparatus used to look at Rushdie's work, Mendes develops five chapters which highlight the different ways in which Rushdie is not only a landmark name but also a cultural authority.

The introduction offers an overview of how culture (high and low) belongs to Rushdie's writing, and it focuses on the dynamics of postcolonial literature and the literary marketplace (Huggan and Brouillette). The angle is to take books as objects, and writers as cultural markers, in the footsteps of Adorno's concept of the culture industry. The study provides the reader with precious close readings of some of Rushdie's texts, drawn from fictions and essays alike. These case studies of "cultural brokerism" look at, for example, "Star Trek," The Wizard of $\mathrm{Oz}$ as well as "Goodness Gracious Me." Mendes' approach focuses on the "non-literary Rushdies" without dismissing completely the "literary Rushdie" (172). Yet when looking at the literary Rushdie, the analysis always relies on the perspective provided by such other writers as Adiga or Chaudhuri. In this sense the study gives a valuable overview of what the cultural marketplace is for 
postcolonial writers, and exposes what happens behind the scenes of the Booker Prize. Rushdie has become a brand name used for niche marketing. The study is thus not about Rushdie's fiction, but as the title suggests about Rushdie's place in the cultural/ literary marketplace, about what the name of Rushdie conveys.

The first chapter, "Rushdie as Gatekeeper," revolves around the seminal question of authenticity and looks into how Rushdie is used as a "power brand" (37). The theoretical backdrop brings together Todd's Consuming Fictions (1996) and Huggan's The Postcolonial Exotic (2001) to assess the Rushdie legacy in the "politics of the book-prize industry" (39). Stepping away from the literary father figure Rushdie often represents, Mendes exposes the making of a cultural landmark, the commodification of Rushdie's Indianness.

5 Using a similar standpoint, chapter 2, "Exploding the Canon," discusses aspects of the literary canon formation. Mendes focuses on the translation rather than the subversion of the British literary canon in Rushdie's fiction, particularly in "Yorick." The other interesting aspect of this chapter is the insight in the anthologist's work. Mendes compares Chauduri's Picador Book of Modern Indian Literature to West and Rushdie's Vintage Book of Indian Writing to examine Rushdie's position on the pre-eminence of English and his allegiance to an India of "mixed tradition" (96). Mendes transposes literary concepts such as mongrelisation and mélange to the industry of writing, of writing India even, to "the marketing of cultural products" (101).

Chapters 3 and 4 embrace non-literary cultural media, and study how Rushdie perceives and uses films, TV series and music in his writing. Yet, the argument is not just about the cinematic intertexts or rock-and-roll lyrics interspersed in his novels. Rather, it underlines Rushdie's criticism of the "Raj Revival" to develop on "the consumption of India-related images" (104). For example, Danny Boyle's Slumdog Millionaire and Baz Lurhman's Moulin Rouge are read against the backdrop of Urry's The Tourist Gaze. Rushdie is no longer taken as a brand name but as a cultural landmark in the "brown culture industry," a concept Mendes borrows from Adorno and Horkheimer to apply it to "postcolonial cultural production" (127).

7 In this thorough analysis, Mendes ascertains that Rushdie may be seen as a cultural gatekeeper as well as a commodified landmark in the book industry, and encourages readers to go beyond the media craze and the controversy, to consider the author's cultural enunciation. In the final chapter, "Rushdie the Public Intellectual," Mendes presents an interesting perspective on Rushdie's "American turn." 9/11, the war on terror, and his knighthood have overshadowed, she argues, that Rushdie is a "liminal cultural actor" (167). And the liminal space he inhabits is not ruled by the artificial binarism of centre/periphery, but reflects new relations nourished by globalisation. In summary, the cultural stakes delineated by Mendes provide valuable ground for new research on Rushdie. 


\section{AUTHORS}

\section{SABINE LAURET}

Sabine LAURET is an Associate Professor at the University of Franche-Comté. She completed her doctoral dissertation, entitled "Voices, languages and discourse: the métissage of the narrative in Amitav Ghosh's novels" in 2010. Her major research interests are Indian writing in English and diasporic cultures. She has published articles on Amitav Ghosh, Jhumpa Lahiri and Monica Ali, and has presented papers on Romesh Gunesekera. 